\title{
Effective ways of teaching pragmatics: humor in the classroom ${ }^{1}$
}

\author{
Formas eficazes de ensinar pragmática: humor na sala de aula
}

\section{Formas efectivas de enseñar pragmática: humor en el aula}

\author{
Ulisses de Oliveira ${ }^{2}$ \\ Sumiko Ikeda ${ }^{3}$ \\ Marcelo Saparras ${ }^{4}$
}

\author{
Keywords: \\ Pragmatics \\ English Teaching \\ Humor \\ Systemic-Funcional \\ Linguistics
}

\section{Abstract:}

Pragmatics takes into account the relations between signs and their users, the speakers. When somebody says "Thanks, I'm not hungry" in response to the statement "You left the door open", your are making a pragmatic mistake, because in such context "thanks I'm not hungry" is an inappropriate reply for the statement "You left the door open". So, pragmatics is the dimension of the study of languages that deals with the relation between signs and their users in their concrete contexts of use, in other words, it is the study of the use of language in communication, particularly the relationships between sentences and the contexts and situations in which they are used. Pragmatics includes the study of: (a) how the interpretation and use of utterances depend on knowledge of the real world; (b) how speakers use and understand speech acts; and (c) how the structure of sentences is influenced by the relationship between the speaker and the hearer. Furthermore, within a SystemicFunctional perspective, language is functional (people use language with a purpose), semantic (the purpose is to make meaning and socially interact with other people), semiotic (meaning making by choice) and contextual (pragmatic) as social interaction influences and is influenced by the context in which it is inserted. In this line of reasoning, the objective of this paper is the consideration that in teaching L2 pragmatics the socioculturally and contextually appropriate (or inappropriate) communication will depend on the teaching of $\mathrm{L} 2$ pragmatics in the classroom in certain instances, as there can be many pragmatically appropriate ways to ask for information, to schedule an appointment, etc. With this in mind, our corpus is based on utterances and situations found in teaching English as L2 environment. Our particular the context is one of a regular English class in a private English school in the state of São Paulo, Brazil in which the L2 teacher used the excerpt of the movie Philomena and comic cartoons to teach English. Some results showed that the great majority of students investigated could not make out the humorous scenes of the video scenes and cartoons before their L2 teacher explained the scenes/cartoons to them mainly due to pragmatic issues. 


\section{Resumo:}

A pragmática leva em consideração as relações entre os signos e seus usuários, os falantes. Quando alguém diz "obrigado, não estou com fome" em resposta à afirmação "Você deixou a porta aberta", está cometendo um erro pragmático, porque, nesse contexto, "obrigado, não estou com fome" é uma resposta inadequada para a pergunta. declaração "Você deixou a porta aberta". Portanto, pragmática é a dimensão do estudo de linguagens que lida com a relação entre signos e seus usuários em seus contextos concretos de uso, ou seja, é o estudo do uso da linguagem na comunicação, particularmente as relações entre sentenças e os contextos e situações em que são usados. A pragmática inclui o estudo de: (a) como a interpretação e o uso de enunciados dependem do conhecimento do mundo real; (b) como os falantes usam e entendem os atos de fala; e (c) como a estrutura das sentenças é influenciada pelo relacionamento entre o falante e o ouvinte. Além disso, dentro de uma perspectiva sistêmico-funcional, a linguagem é funcional (as pessoas usam a linguagem com um objetivo), semântica (o objetivo é criar significado e interagir socialmente com outras pessoas), semiótica (criação de significado por escolha) e contextual (pragmática) como a interação social influencia e é influenciada pelo contexto em que está inserida. Nesta linha de raciocínio, o objetivo deste artigo é considerar que, no ensino da pragmática de $L 2$, a comunicação sociocultural e contextualmente apropriada (ou inadequada) dependerá do ensino da pragmática de L2 na sala de aula em certos casos, pois pode haver muitas maneiras pragmaticamente apropriadas de solicitar informações, agendar uma consulta, etc. Com isso em mente, nosso corpus é baseado em enunciados e situações encontradas no ensino de inglês como ambiente L2. Nosso contexto particular é o de uma aula regular de inglês em uma escola particular de inglês no estado de São Paulo, Brasil, na qual o professor de L2 usou o trecho do filme Filomena e quadrinhos para ensinar inglês. Alguns resultados mostraram que a grande maioria dos alunos investigados não conseguiu distinguir as cenas engraçadas das cenas de vídeo e desenhos animados antes que o professor de L2 Ihes explicasse as cenas / desenhos animados, principalmente por questões pragmáticas.
Palavras-chave:

Pragmática

Ensino de Inglês

Humor

Linguística

Sistêmico-Funcional 


\section{Palabras clave:}

Pragmática

Enseñanza de inglés

Humor

Linguística

sistémica-funcional

\section{Resumen:}

La pragmática tiene encuenta las relaciones entre los signos y sus usuarios, los hablantes. Cuando alguien dice "Gracias, no tengo hambre" en respuesta a la declaración "Dejaste la puerta abierta", estás cometiendo un error pragmático, porque en ese contexto "gracias no tengo hambre" es una respuesta inapropiada para el declaración "Dejaste la puerta abierta". Entonces, la pragmática es la dimensión del estudio de los idiomas que se ocupa de la relación entre los signos y sus usuarios en sus contextos concretos de uso, en otras palabras, es el estudio del uso del lenguaje en la comunicación, particularmente las relaciones entre oraciones y los contextos y situaciones en que se utilizan. La pragmática incluye el estudio de: (a) cómo la interpretación y el uso de los enunciados dependen del conocimiento del mundo real; (b) cómo los hablantes usan y entienden los actos de habla; y (c) cómo la estructura de las oraciones está influenciada por la relación entre el hablante y el oyente. Además, dentro de una perspectiva sistémica-funcional, el lenguaje es funcional (las personas usan el lenguaje con un propósito), semántico (el propósito es dar sentido e interactuar socialmente con otras personas), semiótico (hacer significado por elección) y contextual (pragmático) siendo que la interacción social influye y es influenciada por el contexto en el que se inserta. En esta línea de razonamiento, el objetivo de este trabajo es la consideración de que al enseñar la pragmática L2, la comunicación sociocultural y contextualmente apropiada (o inapropiada) dependerá de la enseñanza de la pragmática L2 en el aula en ciertos casos, ya que puede haber muchas formas pragmáticamente apropiadas de pedir información, programar una cita, etc. Teniendo esto en cuenta, nuestro corpus se basa en las expresiones y situaciones que se encuentran en la enseñanza del inglés como entorno L2. Nuestro contexto particular es el de una clase regular de inglés en una escuela privada de inglés en el estado de São Paulo, Brasil, en la que el maestro de L2 usó el extracto de la película Philomena y dibujos animados para enseñar inglés. Algunos resultados mostraron que la gran mayoría de los estudiantes investigados no podían distinguir las escenas humorísticas de las escenas de video y los dibujos animados antes de que su maestro de L2 les explicara las escenas / dibujos animados principalmente debido a problemas pragmáticos.

1 Texto recebido em 16/09/2019 e aceito para publicação em 23/10/2019.

$2 \quad$ Ulisses Tadeu Vaz de Oliveira. Pós-doutorando no Instituto de Estudos Medievais (IEM) da Universidade Nova de Lisboa (Portugal). Doutor em Linguística Aplicada e Estudos da Linguagem pela Pontifícia Universidade Católica (PUC-São Paulo). Professor na Universidade Federal de Mato Grosso do Sul (UFMS), Brasil. Contato: ulisvaz@gmail.com - https://orcid.org/0000-0002-5479-4905.

3 Sumiko Nishitani Ikeda. Doutora em Lingüística Aplicada e Estudos da Linguagem pela Pontifícia Universidade Católica de São Paulo. Professora titular no curso de pós graduação em Lingüística Aplicada e Estudos da Linguagem (LAEL) da PUCSP, Brasil. Contato: sumiko@uol.com.br - https://orcid.org/0000-0002-5812-5098.

$4 \quad$ Marcelo Saparas: Doutor em Linguística Aplicada e Estudos da Linguagem - PUCSP Professor adjunto da Universidade Federal da Grande Dourados, Brasil. Contato: msaparas@uol.com.br - https://orcid.org/0000-0002-9924-8369 


\section{Effective ways of teaching pragmatics: humor in the classroom}

\section{Introduction}

Meaning seems at once the most obvious feature of language and the most obscure aspect to study. It is obvious because it is what we use language for-to communicate with each other, to convey 'what we mean' effectively. But the steps in understanding something said to us in a language in which we are fluent are so rapid, so transparent, that we have little conscious feel for the principles and knowledge which underlie this communicative ability (LADUSAW, 1992).

According to Bardovi-Harlig (2013, p. 68), pragmaticians have researched many of the things people do with language, including: politeness strategies, making requests, filing complaints, responding with refusals, and giving compliments, and humor. The field has also been greatly enriched by work in cross-cultural pragmatics and interlanguage pragmatics, areas that should be of particular interest to language educators, since being truly successful with a language also involves learners being able to use language "appropriately". Questions of 'semantics' are an important part of the study of linguistic structure. They encompass several different investigations: how each language provides words and idioms for fundamental concepts and ideas (lexical semantics), how the parts of a sentence are integrated into the basis for understanding its meaning (com- positional semantics), and how our assessment of what someone means on a particular occasion depends not only on what is actually said but also on aspects of the context of its saying and an assessment of the information and beliefs we share with the speaker.

In this context, one of the main points for the adhesion of more teachers to the use of pragmatics in teaching has been their own experience within language in use itself, especially owing to a growing number of professionals involved in researches in this field. Moreover, a great number of such professionals are being able to find time to professionally improve through teacher training or educational courses.

Therefore, within this context of teaching and learning languages with the use of pragmatics, we will present a study on the teaching of L2 pragmatics considering the socio-culturally and contextually appropriate (or inappropriate) communication as there can be many pragmatically appropriate ways to ask for information or to schedule an appointment, etc. With the purpose of teaching pragmatics in the classroom, our corpus is based on utterances and situations found in teaching English as L2 environment. Our particular objective is to check the understanding of humorous scenes in L2 lessons at UAM. Specifically, our context is one of a regular English class in a private English school in the state of São Paulo, Brazil when the L2 teacher was using the excerpt of the movie Philomena and other comic cartoons to teach English.

\section{Language \& Culture: Conversational Style}

It seems to be consensual among language teachers that worrying only 
about teaching the grammatical rules of a text is not enough to encourage students to become aware of the rules of communication which necessarily involve intercultural differences.

Communication problems caused by cultural differences called "conversational style" (TANNEN, 1984) involve the ingrained customs of a linguistic community. This style is learned early in life, and it becomes automatic, subconscious and resistant to change. Eventually it becomes apparent in communication.

The author (1984) has emphasized the existence of two major types of conversational styles. They shape the communicative behaviour of individual speakers: a high-involvement style and the opposing high-considerateness style. Tannen's two types of conversational style differ from each other mainly in terms of rate of speech (pace), length of inter- and intraturn pauses, and occurrence (and evaluation) of simultaneous speech:

a) High-involvement style: (I) Shows a minimization of inter- and intraturn pauses; (II) Shows a faster rate of speech; (III) Speaker turns are characterized by frequently occurring simultaneous talk referred to as cooperative overlaps. (IV) Application of minimal responses / backchannels as signals of active listening and to encourage feedback.

b) High-Considerateness style: (I) Shows longer pauses within and between speaker turns; (II) Shows a slower rate of speech; and (III) Shows avoidance of simultaneous talk.

According to her (idem), there is a rapport talk in which simultaneous speech is used to build relationships or rapports among interactants.

\section{Context: a Systemic-Functional perspective}

There are two important notions for pragmatics: (a) the relationship between language and social context, involving the cultural context (genre) and the situational context (register, with its field variables, relationship and mode, referring to the subject, the interacting and constructing the text, respectively); and there is also a third - ideological context, which occupies a higher level of context, referring to positions of power, political biases and assumptions about values, tendencies and perspectives that the interlocutors bring to their texts. The analysis of ideological aspects has been done, among others, by Critical Linguistics (FOWLER, 1991); and (b) the notion of choices: when a choice is made in the linguistic system, what is written or what is said acquires meaning against a background in which are found the choices that could have been made, but which were not, fact important in discourse analysis.

In order to analyse contextual aspects, Martin \& White elect SystemicFunctional Linguistics "a multiperspective model, designed to give analysts complementary lenses for interpreting the language in use." (2005, p. 7). In addition, language is seen as a social practice, the result of the relationship between two fundamental aspects - its systematicity and its functionality (MARTIN; WHITE, 2003). Functionality - what interests me the most - is reflected in discourse through the internal grammatical structure of the language, that is, the functions of language provide the motivations for its form and its structure (HALLIDAY, 1978). In summary, SFL seeks to develop a theory about language as a social process and a methodology that allows a detailed and systematic description of language patterns. Figure 1 represents the stratification of contextual dimensions in constructing a text. 


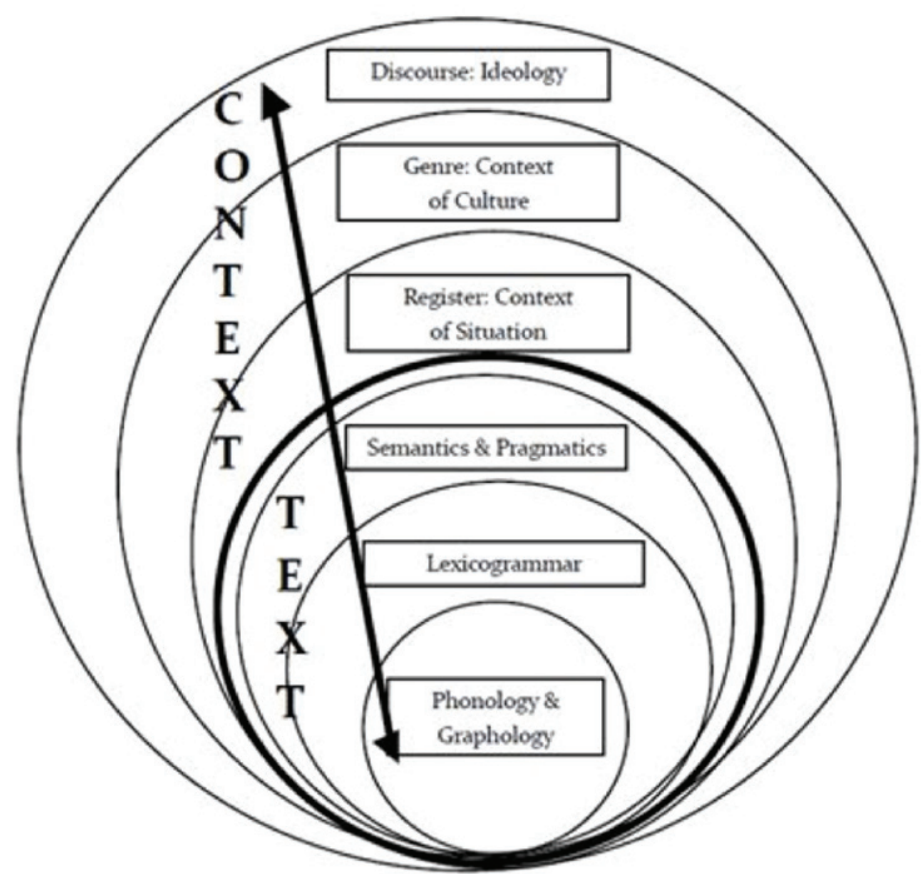

Figure 1 - Representation of Linguistic and Contextual Communicative planes Source: Martin (1992, p. 496)

The case study presented here emphasizes the context of culture, and according to $\mathrm{Li}$ (2010), there's an overall understanding that sociopolitical or sociocultural ideologies are intertwined with language and discourse. A basic premise of all forms of Critical Discourse Analysis is that the use of language in discourse implies ideological meanings and that there are discursive restrictions on the use of language and the meanings involved (VAN DIJK, 1993; FOWLER, 1996; FAIRCLOUGH, 1995).

\section{Frames}

Frames are mental knowledge structures - our knowledge of the world - that capture the typical features of a situation to ensure consistency and, according to Minsky (1977), they can be selected or retrieved when necessary. In the following example (Figure 2), people followed each frame that they internalized in their culture.
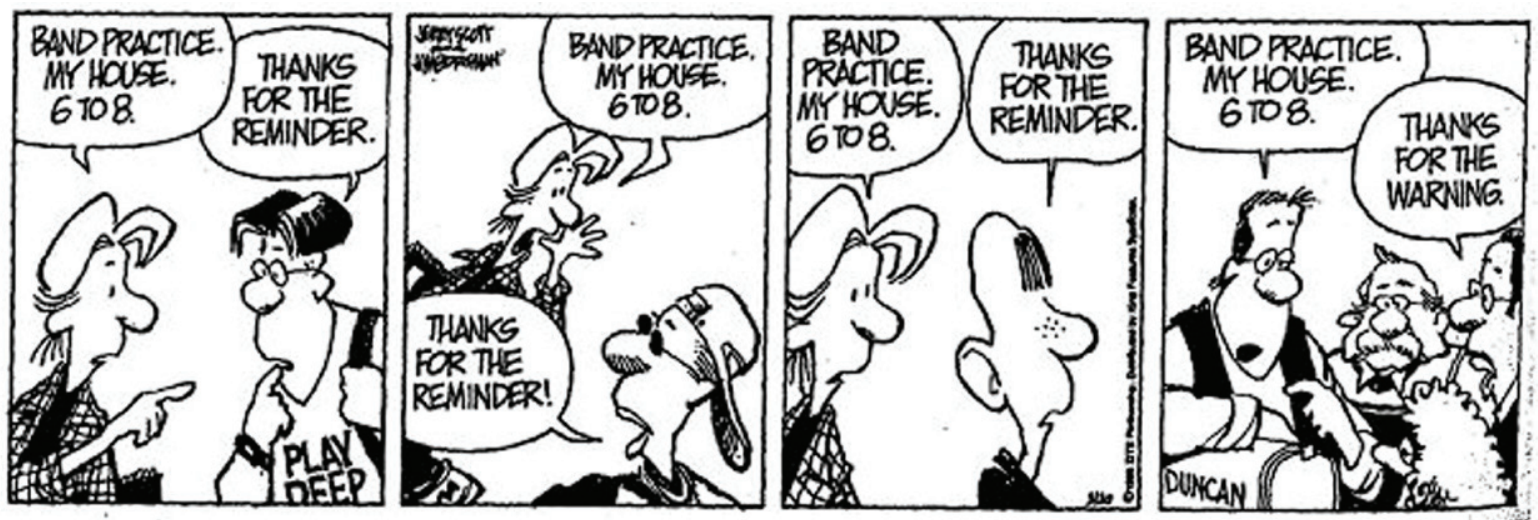

Figure 2 - Cartoon an application of the frame notion Source: Crystal (2011) 
In Pragmatics the notion of frame is important considering that "definitions of a situation are built up in accordance with principals of organization which govern events, and our subjec-

On a very hot day, I said in class in Japan:

Me: How hot!

Student: It's really hot! (Attention to the semantic meaning.)

This kind of performance sometimes lead to misunderstandings, as we explain in the next section.

\section{Pragmatics and Communication}

From a semiotic standpoint (meaning-making), more than intelligibility, pragmatics is at the core of miscommunication when speakers neglect (or are unable to depict) contextual dimensions. We can see a few examples of that as follows:

a) Face-work - "Facework represents an important mediation of the intersection between an individual's private self-conception and the individual's need to cooperate-or not-in a society, especially at the interpersonal and organizational levels of communication. More clearly, facework builds on the notion of a metaphorical 'face', which represents how an individual is viewed-that is, respectfully or not-by others in an interaction" (FLETCHER et al., 2014).

\section{Example:}

"Go out" and "go ahead" have similar semantic meanings, but they differ in pragmatic terms. This is what happened in Brazil when a student, trying to speak English with an English-native teacher who was visiting our university said, "Please, go out!" tive involvement in them" (GOFFMAN, 1974 , p. 34). In the examples below, in a classroom interaction, students followed each frame that they internalized in their culture.

In Brazil, the reaction was different:

Me: How hot!

Student: Do you want me to open the door?

(Attending to the pragmatic meaning.)

b) Marketing blunder - Meanings of words depend on the context of experience, beliefs, or practices of a locality (Fillmore \& Atkins, 1992). In Marketing, a blunder is a stupid or careless mistake which leads to bad results in consumers' stance towards a product/service (RICKS, 1983, p. 22)

\section{Example:}

- In Spain, sales of the GM Corsa did not take off when the car was offered under the name NOVA (No va= do not go);

- Mitsubishi sells the $4 \times 4$ model in Brazil and Great Britain under the name of $\mathrm{Pa}$ jero, but in Spanish-speaking countries it renamed it to Montana, because "pajero" means "to masturbate" in these places.

c) Regional Culture - Language and culture can hardly be separated. "We consider that language is one of the systems of expression of a culture and that different languages have preferences that are influenced by culture" (GRABE; KAPLAN, 1989, p. 50).

Example:

Two Japanese translators, when working on the novel Quincas Berro d'agua - a Brazilian regional novel by Jorge Amado - translated "she entered the room swinging the chairs", when, in fact, the word "cadeiras" (pt.) (chairs) has the regional meaning of hips. 
d) Humor - Your understanding of humor can be seriously inhibited if you are not familiar with the context of culture.

Example:

“To Wee Pig from Big Pig. Grunt! Grunt!"

Actually, the text above is a St. Valentine's Day greeting. On a certain day of the year newspapers print messages of love from people pretending to be animals. From all the examples previously presented, humor is one that demands greater cultural proficiency; in other words, the way one sees differences, responds positively (or not), engages and adapts.

Hay (2000) points out four main functions of humor: to generate solidarity; to control; to explore and confront; to set boundaries. Solidarity and power are apparently on opposite sides, but they are complementary elements. When using humor successfully, the speaker's status is assessed as positive. It entertains the speaker and shows that the interlocutors share the same ideas and conceptions, creating and maintaining solidarity among them. For the author, exploring and confronting are framed in the psychological category of humor and such functions serve to put someone in a certain position or to clarify a more serious situation (HAY, 2000, p. 32).

In the next section, we will explore a case study of $L 2$ learning that encompasses humor from a pragmatic standpoint.

\section{Methodology}

In order to teach aspects of pragmatics, we implemented a methodology focused on humor due to the students' interest. The research group was composed of 27 students from a private university in the state of São Paulo, Brazil. There, English as an in-curriculum discipline was offered for the business college. The lessons observed dealt with humor. It was an attempt for making the classes more appealing to the students. There was a didactic sequence of activities divided into five classes, as follows:

1) Students saw the following scene of the movie Philomena and were shown comic cartoons as well.

As an example, here's the description of the movie scene seen in class: "Philomena and her daughter meet Martin at a restaurant. He asks Philomena how she's doing about her hip replacement. Martin makes a joke that if her replacement hip wasn't made of titanium, they'd have to oil her like the Tin Man. She doesn't understand it's a joke and takes his comments as literal. Philomena's daughter explains that he's being funny. Martin agrees, and then seriously explains that his mother actually has advanced osteoporosis in both of her knees; to this comment, Philomena laughs hysterically, not being able to gauge fact from fiction."

2) Students answered about their insights and perception of humor from the scene by answering surveys in class. Then, an open discussion followed in order to allow students to share their points of view from the scene.

3) The following classes focused on teaching context, pragmatics and communication and humor, as described below and observed in Figure 3:

(a) Context: ideological, cultural (cf. Martin 1992), with a special regard to the cultural aspects that have to be considered in the meaning-making process.

(b) Pragmatics and communication: teachers taught important aspects for (mis)communication with the examples presented in the previous section of 
this article. They are face-work, marketing blunders, cultural differences and humor.

(c) Humor: classes dug into the complexity of humor by analyzing five cartoons based on utterances and situations found in teaching English as L2 environment (example, Figure 3). The focus was the utterance markers of four categories (cf. Burguers \& van Mulken 2012): (1) typographic markers, which are the ones that include the use of striking typography, like the use of quotation marks and capitalization; (2) morpho-syntactic markers. These markers draw the reader's attention by presenting an utterance with a striking syntactic structure or morphology. This category includes markers such as exclamations, tag questions, negations, focus topicalization, elongation and diminutives. By showing the dissociative or hesitative stance of the communicator, these markers draw attention to the ironic nature of a statement (Kovaz et al. 2013); (3) schematic markers, which are based on schemes like figures that deal with word order and sound patterns: a deviation from the ordinary arrangement of words and sounds, like alliteration and rhyme; and (4) other tropes, which are rhetorical figures that focus on meaning operation, in that readers should reinterpret the propositional ("literal") meaning of the utterance.

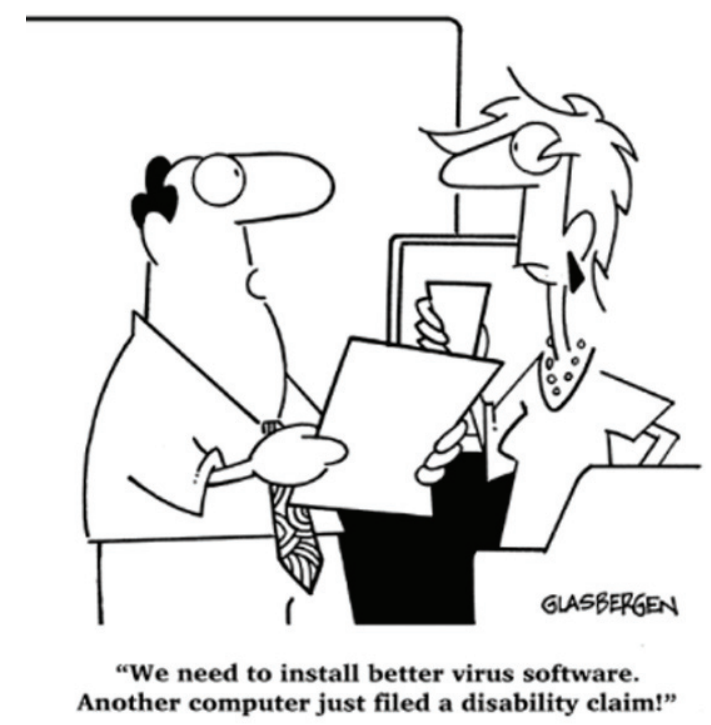

Figure 3 - Example of humor in a Cartoon analysed in class Source: Glasbergen (2014)

4) Teachers were given a survey where they could report about their experience in these five classes and about their views about what could be done in order to improve/facilitate students' understanding/learning about the pragmatic issues involved in the activity presented.

5) The last class was reserved for a re-evaluation of the scene of the movie Philomena.
Results are described in the next section.

\section{Case Study Results: Philomena}

In this research, analysis showed that, when mapping levels of culture, at first, students could not grasp the humor from the scene, reacting just like Philomena in the movie. Then, after setting up frame conditions, professors started investigating what went wrong. 
Students answered surveys to help professors in mapping contextual aspects, levels and dimensions that led to misunderstanding.

As an important variable to be discarded as a factor of misunderstanding, researchers determined the levels of proficiency of students. Tests were conduct- ed based on the CEFR standard5. Charts 1 and 2 indicate that proficiency levels were not determinant for results since: Students were at a higher level of proficiency, from B1 to $\mathrm{C} 2$ (Chart 1), and they reacted to humor on a similar rate $(48 \%$ - B1; 68\% - B2; 60\% C1/C2), with B2 students outnumbering $\mathrm{C} 1 / \mathrm{C} 2$ students in responsiveness to humor.

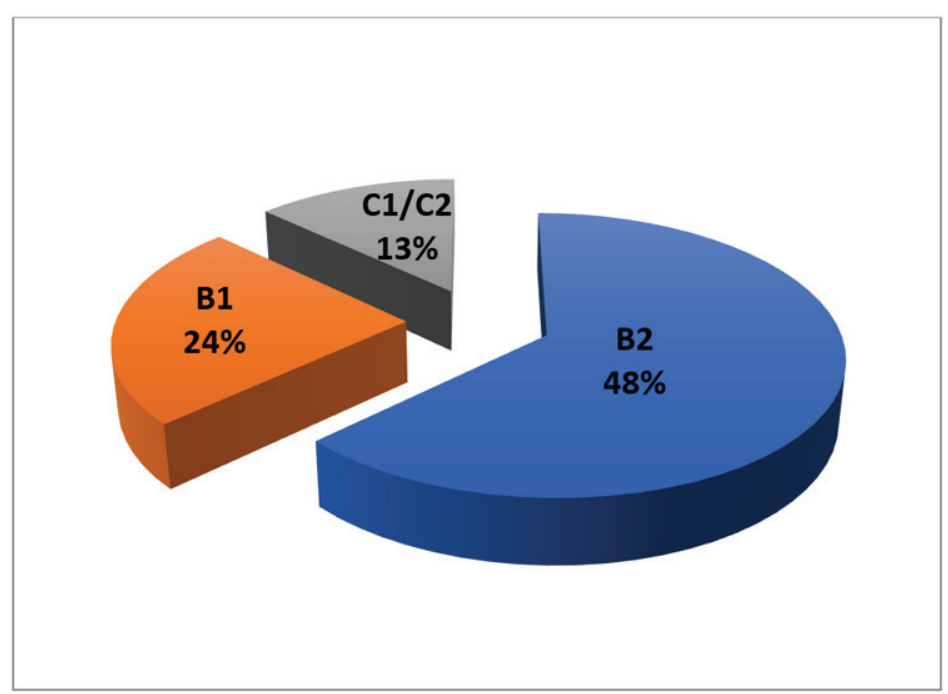

Chart 1 - Proficiency Levels

Source: Authors

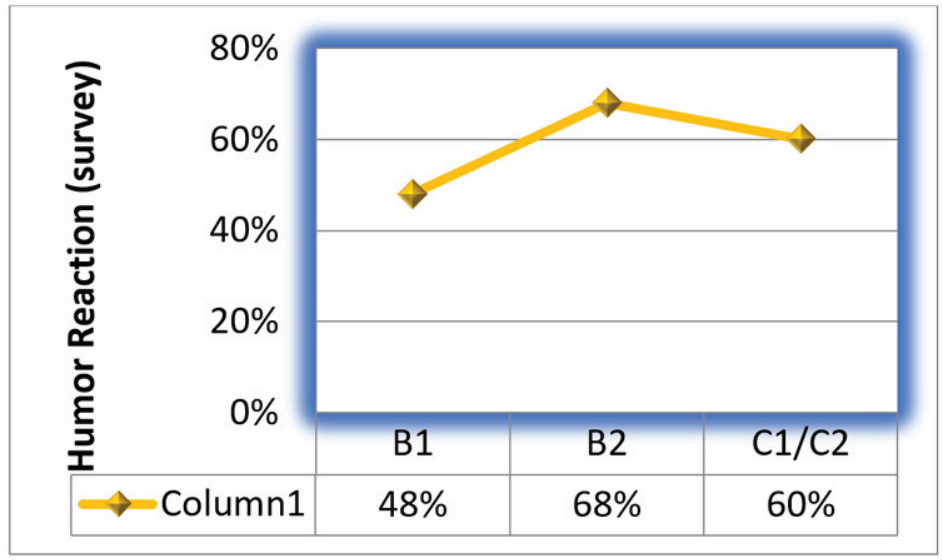

Chart 2 - Humor Reaction

Source: Authors

5 Common European Framework of Reference for Languages. The six reference English levels are widely accepted as the global standard for grading an individual's language proficiency. The CEFR organises language proficiency in six levels, A1 to C2, which can be regrouped into three broad levels: Basic User, Independent User and Proficient User, and that can be further subdivided according to the needs of the local context. 
As expected, after teachers provided the necessary frames: cultural, situational and ideological dimensions that supported that interaction, students made up their minds on how funny the scene was. Beforehand, students analyzed the complexity of humor in five cartoons to juxtapose elements of humor in different genres, in this case, cartoons and movies. Students observed that in movies, tropes like the typographic, morpho-syntactic and schematic ones are mainly detected through paralinguistic features. In other words, aspects of spoken communication that may encode humor by adding emphasis or shades of meaning to what people say. In the scene, body language, gestures, facial expressions, tone and pitch of voice were all extremely important as students noted the characters in the movie "adjusting" to be funny.
Teachers conducted discussions in class about the scene and other movie scenes were presented to reinforce humor in similar contexts. Then, students answered a questionnaire to state their second-guess on the Philomena's scene (Chart 3). Before answering the questionnaire, teachers made students aware of theories about culture and how they can vary in multiple contexts. Focus was on the model developed (SCHMITZ; TARTER; SINE, 2012), and questions varied in terms of: Was the scene funny? How funny? Did you understand the scene? If not, why didn't you understand it at first? What would help you understanding the scene at first? What is important to understand humor? What would facilitate your understanding? Other ideas.

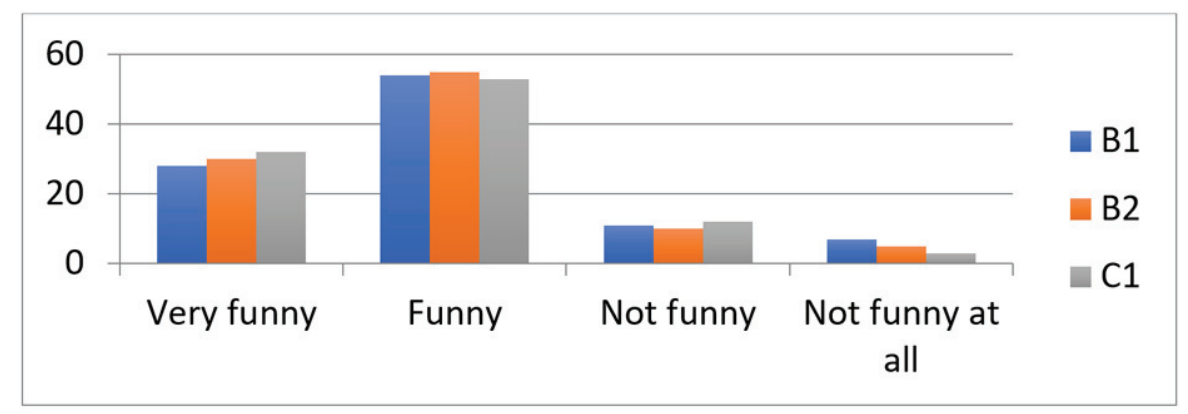

Chart 3. Survey: Did you find the scene funny?

Source: Authors

Analysis helped mapping misunderstanding by establishing a network of cultural background among interactants and audience (Figure 3).

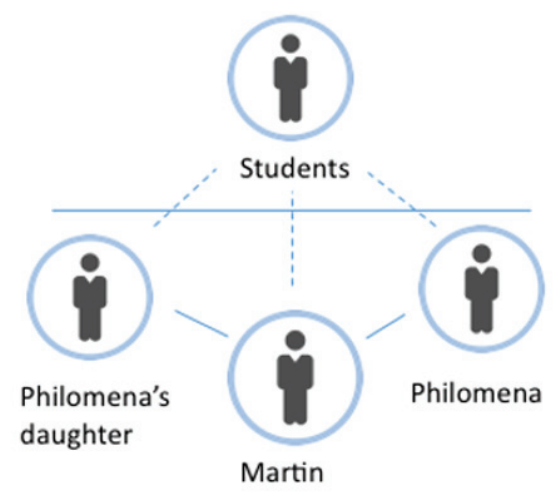

Figure 3. Cultural Proficiency network Source: Authors 
The cultural network in Figure 3 shows that grasping humor from the scene was even more challenging for our students since they were at a more distant cultural background than the characters in the movie. Characters were misunderstood for being misaligned in terms of age, instruction level and social background, and these notions were maximized for students in all of these cultural aspects.

To sum up, research provided some interesting results which implied that the great majority of students could not make out the humorous scenes before their L2 teacher explained the scenes to them. Specifically:

- Language teaching should focus on culture as it is strengthened through its expression.

- We lack intercultural competence.

- We should understand people's values in order to understand their motivations.

- We need to know the context before watching a movie.

- We should learn about intercultural competence together with language learning.

- Critical thinking and assumptions should be included in language learning.

- It is necessary for us to avoid misunderstandings to be learned about the context of culture.

- We need to be involved in intercultural competence in the foreign language classroom.

- Difficult vocabulary should be taught before watching a movie.

\section{Concluding Remarks}

This study proposes that the study of pragmatics in the classroom is necessary as even the so-called more advanced students in English have difficulty understanding meaning from humor utterances from authentic movies even when they can make out the language delivered. Arguing that a pragmatic knowledge of the movies and cartoons dealt with in class are not enough to cause the students to feel the humor involved in those, this study provides a case study proposed in the classroom envi- ronment with the students and teachers during five English lessons, which were designed to promote language acquisition through a non-traditional, more playful approach based on humor. Drawing upon students' reaction to the scene and cartoons, as expected, after the teacher provided the necessary frames: cultural, situational and ideological dimensions that supported that interaction, students made up their minds on how funny the scene was. Despite the fact that the students reposted that they had there was comprehension considering the language used, most of them reposted that they had difficulty understanding why that scene or cartoons were considered humorous. As the surveys (27) were analysed, we realized that most students argued that the difficulty understanding the scene was that none of them could grasp the context of what was going on in the scene (92\%). Also, the analysis of answers made reference to the fact that language classes are more focused on the morphosyntactic aspects of the language rather than other aspects such as culture and context. Despite word decoding and understanding, students did not display enough cultural awareness from their English language classes. Students should be aware that there will be will inevitably problems of difference in cultural interpretation when learning a foreign language.

The teacher conducted discussions in class about the scene and other movie scenes were presented to reinforce humor in similar contexts. She reported that after clarifying about the cultural issues in the scene and about form, function and meaning of the utterances, the students showed comprehension and could detect humor in the material presented to them. The survey distributed to students showed that there was a belief that Language teaching should focus on culture as it is strengthened through its expression. The teacher and students believed that the latter lacked intercultural competence and that they needed to know the context before watching a movie. Both the teacher and students reported that critical thinking and 
assumptions should be included in language learning lessons in order to avoid misunderstandings. Besides, it's their belief that culture context should be explicitly taught so that students could be involved in intercultural competence in the foreign language classroom. Last but not least, not only the teacher but also the students involved in the study agree that difficult vocabulary should be taught before watching movies or analyzing cartoons.

\section{References}

BARDOVI-HARLIG, K. Developing L2 pragmatics. Language Learning, 63(s1), p. 68-86, 2013.

BURGERS, C.; VAN MULKEN, M. Humor markers. The Routledge handbook of language and humor, $\mathrm{p}$. 385-399, 2017.

CRYSTAL, D. Internet linguistics: A student guide. London: Routledge, 2011.

EGGINS, S. Introduction to systemic functional linguistics. London: A\&C Black, 2004.

FAIRCLOUGH, N. Critical discourse analysis: The critical study of language. Essex: Longman, 1995.

FILLMORE, C. J.; ATKINS, B. T. Toward a framebased lexicon: The semantics of RISK and its neighbors. Frames, fields, and contrasts: New essays in semantic and lexical organization, 103, p. 75-102, 1992.

FLETCHER, C. V. et al. Establishing cross-cultural measurement equivalence of scales associated with face-negotiation theory: A critical issue in cross-cultural comparisons. Journal of International and Intercultural Communication, 7(2), p. 148-169, 2014.

FOWLER, R. Language in the News: Discourse and Ideology in the Press. Londpon: Routledge, 2013.

FOWLER, R. On critical linguistics in Texts and Practices: Readings in Critical Discourse Analysis. London: Routledge, 1996.

GLASBERGEN, D. Cartoon ID: toon-321. Glasbergen.com. Available at http://www.glasbergen.com/ ngg_tag/office-humor-cartoons/nggallery/image/weneed-to-install-better-virus-software-another-computer-just-filed-a-disability-claim-2.
GOFFMAN, E. Frame analysis: An essay on the organization of experience. Cambridge: Harvard University Press, 1974.

GRABE, W.; KAPLAN, R. B. Writing in a second language: Contrastive rhetoric. In: JOHNSON, D. M.; ROEN, D. H. (eds.) Richness in writing: Empowering ESL students. London: Addison-Wesley Longman, 1989. p. 263-283.

HALLIDAY, M. A. Language as social semiotic. London: Edward Arnold \& Co, 1978.

HAY, J. Functions of humor in the conversations of men and women. Journal of pragmatics, London, Elsevier, 32(6), p. 709-742, 2000.

KOVAZ, D.; KREUZ, R. J.; RIORDAN, M. A. Distinguishing sarcasm from literal language: Evidence from books and blogging. Discourse Processes, 50(8), p. 598-61, 2013.

LADUSAW, W. A. Expressing negation. Semantics and linguistic theory. Vol. 2. Maryland: University of Maryland Press, 1992. p. 237-260.

LI, J. Transitivity and lexical cohesion: press representations of a political disaster and its actors. Journal of Pragmatics, 42.12, p. 3444-3458, 2010.

MARTIN, J. R. 1992. "Genre and literacy-modeling context in educational linguistics". Annual review of applied linguistics 13: 141-172.

MARTIN, J. R.; WHITE, P. R. R. The evaluation of language: Appraisal in English. Hampshire: Palgrave Macmillan, 2005.

MARTIN, J. R.; WHITE, P. R. The language of evaluation (Vol. 2). Basingstoke: Palgrave Macmillan, 2003.

MINSKY, M. Frame theory. In: JOHNSON-LAIRD, P. N.; P. C. Thinking: Reasings in Cognitive Science. Cambridge: Cambridge University Press, 1977. p. 355-376.

RICKS, D. A. Big business blunders: Mistakes in multinational marketing. London: Irwin Professional Publishing, 1983.

SCHMITZ, J.; TARTER, L.; SINE, J. Understanding the cultural orientations approach: An overview of the development and updates to the COA. TMC Inc., A Berlitz Company, 2012.

TANNEN, D. Conversational style: Analyzing talk among friends. Oxford: University Press, 1984.

VAN DIJK, T. A. Principles of critical discourse analysis. Discourse \& society, 4(2), p. 249-283, 1993. 